\title{
The Effect of Needle Sizes for Sample Adequacy in Thyroid Nodule Fine-Needle Biopsies
}

\section{Tiroid Nodül İnce İğne Biyopsinde Yeterli Tanısal Numune Almaya İğne Boyutunun Etkisi}

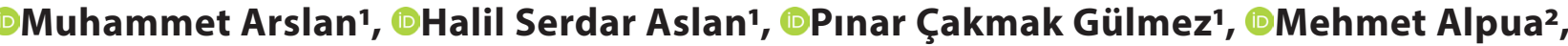

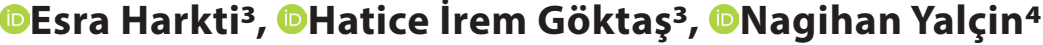 \\ 'Pamukkale University School of Medicine Department of Radiology, Denizli, Turkey \\ 2Pamukkale University School of Medicine Department of Internal Medicine, Denizli, Turkey \\ 3Pamukkale University School of Medicine, Denizli, Turkey \\ ${ }^{4}$ Pamukkale University School of Medicine Department of Patology, Denizli, Turkey
}

\begin{abstract}
Aim: The aim of this study was to compare the diagnostic adequacy of thyroid samples obtained with 22-Gauge and 27-Gauge needles.

Material and Method: From January 2019 to December 2019, 860 patients with thyroid nodules who underwent ultrasound-guided fine-needle biopsies were included in this retrospective study. The results of the samples taken were classified cytologically according to the Bethesda 2017classification. Sample adequacy rates were calculated for each group and compared using chi-square tests.
\end{abstract}

Results: Our cytological results were reported as 157 (18.3\%) inadequate materials (Bethesda1). There were no statistically significant differences among the adequacy rates achieved with 22 - and 27 -gauge needles ( $80.4 \%$ and $83.2 \%$, respectively; $\mathrm{P}>0.05$ ). There was no significant or permanent complication.

Conclusion: There was no difference between 22 and 27-Gauge needle sizes in diagnostic adequate sample. Prospective randomized controlled studies are needed to examine the relationships between nodule, needle, and patient dependent variables.

Keywords: Fine-needle aspiration biopsy, thyroid nodule, adequacy, needle size

\section{Öz}

Amaç: Bu çalışmanın amacı 22 ve 27-Gauge boyutlu iğneler ile yapılan tiroid biyopsilerinde alınan sitolojik örneklerin patolojik olarak tanı verme yeterliliğini karşılaştırmaktır.

Gereç ve Yöntem: Bu retrospektif çalışmaya Ocak 2019-Aralık 2019 tarihleri arasında 860 hastaya ultrason kılavuzluğunda yapılan tiroid ince iğne biyopsileri dahil edilmiştir. Alınan örneklerin sonuçları sitolojik olarak Bethesda 2017 sınıflamasına göre sınıflandırılmıştır. Örneklerin tanı yeterlilikleri her grup için ki-kare testi ile analiz edilmiştir.

Bulgular: Toplamda 157 (\%18,3) tanısal olmayan mateyeral patoloji sonucu olarak rapor edildi (Bethesda 1). Araştırmamızda 22 ve 27-Gauge boyutlu iğneler ile elde edilen örneklerin tanısal yeterlilik oranları arasında istatistiksel olarak anlamlı bir farklılık yoktu (sırasıyla; $\% 80,4$ ve \%83,2, P>0,05). Kalıcı veya ciddi bir komplikasyon görülmedi. Sonuç: İnce iğne biyopsisinin yeterli numune vermesi açısından 22 ve 27 Gauge iğne boyutları arasında fark görülmemektedir. İğneye, nodülün özelliğine ve hastaya bağlı değişkenler arasındaki ilişkileri incelemek için prospektif randomize kontrollü çalışmalara ihtiyaç vardır.

Anahtar Kelimeler: Ince iğne aspirasyon biyopsisi, tiroid nodülü, yeterlilik, iğne boyutu

Corresponding (iletişim): Muhammet Arslan, Pamukkale University School of Medicine Department of Radiology, Division of Interventional Radiology, Denizli, Turkey

E-mail (E-posta): dr.marslan@hotmail.com

Received (Geliş Tarihi): 06.10.2020 Accepted (Kabul Tarihi): 11.04.2021 


\section{INTRODUCTION}

Fine needle aspiration biopsy (FNAB) of thyroid is a minimal invasive diagnostic method used to distinguish malignancy from benign nodules. After the use of ultrasound guidance for FNAB which has high sensitivity and specificity, the rate of nondiagnostic pathological results has been significantly reduced. ${ }^{[1,2]}$ FNAB was described in 1930 by Martin et al. ${ }^{[3]}$ Today FNAB is commonly performed under ultrasound (US) guidance. The complication rates of FNAB under the guidance of US are low because needle, nodule, and surrounding tissues can be seen in real-time during the procedure. The most important problem with FNAB is non-diagnostic samples which reach up to $25 \% .{ }^{[4]}$ Needle size used during FNAB varies from 21 gauge to 27 gauge. [5] 25-27 gauge needles are mostly used in western countries such as Europe and America, while 21-22 gauge needles are used more frequently in Japan. ${ }^{[6]}$ Thick needles increase the contamination rate of the sample taken, while thinner needles make it difficult to direct the needle during the procedure. Liquid-based cytological examinations are suggested to reduce non-diagnostic biopsy. ${ }^{[7]}$ There are few articles on whether the needle size affects the pathological diagnosis..$^{[4,8,11]}$ In none of these articles, direct microscopic examination and liquid-based cytological examination were performed together. US-guided FNABs carried out in our unit are both evaluated conventionally by spreading the samples on glass slides and by liquid-based cytological examination. In this study, we aim to compare the pathological diagnostic ability of 22 gauge and 27 gauge needles.

\section{MATERIAL AND METHOD}

For our study, approval was obtained from the ethics committee of our institution and the Helsinki Declaration was followed during the study. 860 US-guided FNAB performed between January 2019 and December 2019 were evaluated retrospectively. Biopsies were performed by two interventional radiologists who have at least five years of experience in FNAB. One of our interventional radiologists who performed biopsy preferred the $22 \mathrm{G}$ needle and the other preferred the $27 \mathrm{G}$ needle.

The exclusion criteria were that biopsy was not performed under ultrasound guidance, or 22 Gauge or 27 Gauge needles were used during the biopsy. In addition, biopsies performed by physicians with less than 5 years of experience were also excluded. While performing biopsies, it was used with BK 1202 (BK Ultrasound, Herlev, Denmark) US device and 6-18 MHz linear probe as a guide. The procedures were performed while the patient was in supine position and neck in extension. First, skin sterilization was achieved with Povidone İodine solution. After the sterile sheath was put on to the probe, biopsy was performed. Some of the sample taken was spread on the slide and some were put in a liquid-based biopsy solution. Only 2 procedures were performed under general anesthesia due to anxiety. Anesthesia was not used in other procedures.

Biopsy results were evaluated cytologically by a single pathologist according to the Bethesda 2017 classification. ${ }^{[13]}$ Bethesda classification and general clinical approach according to classification are shown in Table 1. We will compare the pathological diagnostic ability of 22 gauge and 27 gauge needles according to Bethesda 2017 classification.

\begin{tabular}{|c|c|}
\hline Diagnostic Category & Usual Management \\
\hline 1- Non-diagnostic or unsatisfactory & Repeat FNAB \\
\hline 2-Benign & Clinical and sonographic follow-up \\
\hline $\begin{array}{l}\text { 3- Atypia of undetermined } \\
\text { significance or follicular lesion of } \\
\text { undetermined significance }\end{array}$ & $\begin{array}{c}\text { Repeat FNAB, molecular testing, or } \\
\text { lobectomy }\end{array}$ \\
\hline $\begin{array}{l}\text { 4- Follicular neoplasm or suspicious } \\
\text { for a follicular neoplasm }\end{array}$ & Molecular testing, or lobectomy \\
\hline 5- Suspicious for malignancy & $\begin{array}{l}\text { Near-total thyroidectomy or } \\
\text { lobectomy }\end{array}$ \\
\hline 6- Malignant & $\begin{array}{l}\text { Near-total thyroidectomy or } \\
\text { lobectomy }\end{array}$ \\
\hline
\end{tabular}

SPSS 22.0 package program was used for statistical analysis of the data. Continuous variables are expressed as mean \pm standard deviation, categorical variables as numbers and percentages. The differences between categorical variables were examined by chi-square analysis. In all analyses, $\mathrm{p}<0.05$ was accepted statistically significant.

\section{RESULTS}

Among 860 patients we included in our study, 679 were female (\% 79) and 181(\% 21) were male. The average age of our patients was 53, and our youngest patient was 9 years old, and our oldest patient was 89 years old. The results of 157 patients (18.3\%) came as non-diagnostic pathology. This rate was calculated as $17 \%$ in females and $22.6 \%$ in male patients. The majority of the diagnostic sample results according to the Bethesda classification are shown in Table 2. 22G needle was used in 438 patients whereas $27 \mathrm{G}$ needle was used in 422.86 of $438(19.6 \%)$ samples taken with a 22-gauge needle and 71 of $(16,8 \%)$ samples taken with a 27 -gauge needle were pathologically non-diagnostic. According to the statistical analysis, there was no difference between needle size and non-diagnostic results of pathologic samples $(P=0.286)$

The most common complication was temporary local pain. 9 patients (1.04\%) had intrathyroidal bleeding and 2 patients had hematoma adjacent to the carotid artery. These complications regressed during follow-up. Dizziness was observed in some of our patients due to anxiety. Since the number of complications is very low, no statistical analysis could be performed to show that that is related to needle size.

\section{Table 2. Our pathological diagnoses according to the 2017 Bethesda} reporting system

\begin{tabular}{lcc} 
Diagnosis & $\mathbf{n}$ & Percent (\%) \\
\hline 1 & 157 & 18.3 \\
2 & 663 & 77.1 \\
3 & 10 & 1.2 \\
4 & 1 & 0.1 \\
5 & 17 & 2 \\
6 & 12 & 1.4 \\
\hline
\end{tabular}




\section{DISCUSSION}

US-guided FNAB is an effective and low-cost method for evaluating thyroid nodules and has a significantly low morbidity rate. ${ }^{[11,14]}$ The most important problem encountered in the procedures for the search for the optimal needle size to be used during FNAB is the non-diagnostic pathology results due to the insufficient sample, which can be seen in up to $25 \%$. In our study, although the diagnostic pathological result rate $(83.2 \%)$ of the samples taken with a 27 - gauge needle was slightly higher than that of a 22 -gauge needle (80.4\%), the effect of the biopsy needle diameter on diagnostic result rate was not statistically significant $(p=0.286)$. In the study conducted by Tangpricha et al., 21-gauge and 25-gauge needles were compared, and as a result of the study, it was stated that more cells appeared in biopsies taken with 25 -gauge needles, but the rate of diagnosis was not changed. Despite the fact that more cells are present in this study, the authors attributed the rate of diagnosis not to be affected by blood contamination. ${ }^{[1]]}$

In many research articles about the effect of needle size on diagnostic adequacy, needle size was found to be unrelated to non-diagnostic samples similar to our study. ${ }^{[4,6,9-12,14]}$ The only study showing the higher diagnostic rate with smaller size needles is the research by Degirmenci et al. ${ }^{[8]}$

FNAB is a well-tolerated procedure that has only minor temporary complications and does not require local anesthesia. ${ }^{[6]}$ In our procedures, no complications requiring intervention were observed. It was said that the degree of pain after FNAB could be related to needle size, the number of needle penetration, length of aspiration time, location of nodules, operator experience, and patient-related factors. ${ }^{[15]}$ In biopsies with thinner needles, the pain may decrease due to the needle size on the other hand the pain may increase as the duration of the needle being in tissue may increase. In studies conducted until now, it hasn't been shown statistically that the pain is related to the size of the biopsy needle. ${ }^{[8,12,16]}$ And also, the experience of the operator performing the procedure wasn't found to be related to the degree of pain. [17] Hemorrhage may occur in intranodular, parenchymal, subcapsular, or parathyroid tissues. It usually heals without any interventions. Anticoagulant antithrombotic drugs should be discontinued 3-10 days before FNAB, due to the increased risk of hemorrhagic complications. ${ }^{[18]}$

It has been reported that on-site evaluation of the FNAB specimens by a cytopathologist decrease the biopsy repetition rates and false-negative results and increase the biopsy success. ${ }^{[4,19]}$ Stacul et al. found that on-site cytopathological evaluation reduced the diagnostic failure rates from $14 \%$ to $4 \% .{ }^{[20]}$ The on-site cytopathological evaluation may prolong the biopsy period on the day of the procedure but can reduce the coming back to the hospital and feeling psychologically uncomfortable. ${ }^{[4]}$ In fact, it was reported that the cytotechnician and cytopathological were not different in terms of diagnostic adequacy in the on-site evaluation of FNAB samples. ${ }^{[2]}$ In our study, on-site cytopathological evaluation was not performed. However, if possible, we think that it is important to evaluate the pathology at the processing site in order to protect the patient from repeated biopsies.

There were some limitations in our study. First of all, since the study was conducted retrospectively, the information presided from patient file records could be analyzed. In our study, only 22-gauge and 27-gauge needles could be compared. However, we think that it is necessary to evaluate the needles in intermediate size such as 25 -gauge. In addition, we think that needle preference may vary depending on the structure of the nodule because of the possibility of the fine needle's bending and inability to enter the nodules with high calcification. Therefore, we suggest that the structure of the nodule should be taken into consideration in future prospective studies.

\section{CONCLUSION}

As a result, in our study, the adequacy of thyroid biopsy samples obtained with different sizes of needles (22 and 27-gauge) was compared and no significant difference was found between them. To reduce the risk of non-diagnostic samples, specimens are recommended to be evaluated by the cytopathologist at the processing site. Prospective randomized controlled studies are needed to examine to relationships between nodules, needles, and patient dependent variables.

\section{ETHICAL DECLARATIONS}

Ethics Committee Approval: The study protocol was approved by the Medical Ethics Committee of Pamukkale University (Permission granted: 25.06.2020, Decision no: 2020/37894).

Informed Consent: Because the study was designed retrospectively, no written informed consent form was obtained from patients.

Referee Evaluation Process: Externally peer-reviewed.

Conflict of Interest Statement: The authors have no conflicts of interest to declare.

Financial Disclosure: The authors declared that this study has received no financial support. Author Contributions: All of the authors declare that they have all participated in the design, execution, and analysis of the paper, and that they have approved the final version.

\section{REFERENCES}

1. Can AS, Peker K. Comparison of palpation-versus ultrasound-guided fineneedle aspiration biopsies in the evaluation of thyroid nodules. BMC Res Notes 2008;1:12.

2. Cesur M, Corapcioglu D, Bulut S, et al. Comparison of palpation guided fine-needle aspiration biopsy to ultrasound-guided fine-needle aspiration biopsy in the evaluation of thyroid nodules. Thyroid 2006; 16:555-61.

3. Martin HE, Ellis EB. Biopsy by needle puncture and aspiration. Ann Surg 1930; 92:169-81. 
4. Cerit M, Yücel C, Göçün PU, et al. Ultrasound-guided thyroid nodule fineneedle biopsies comparison of sample adequacy with different sampling techniques, different needle sizes, and with/ without onsite cytological analysis. Endokrynol Pol 2015; 66:295-300.

5. Cappelli C. Pirola I, Agosti B, et al. Complications after fine needle aspiration cytology: a retrospective study of 7449 consecutive thyroid nodules. Br J Oral Maxillofacial Surg 2017; 55:266-9.

6. Tanaka A, Hirokawa $M$, Higuchi $M$, et al. Optimal needle size for thyroid fine needle aspiration cytology, Endocrine Journal, 2019; 66(2):143-7.

7. Fischer AH, Clayton AC, Bentz JS, et al. Performance differences between conventional smears and liquid-based preparations of thyroid fine needle aspiration samples: analysis of 47076 responses in the college of American pathologists interlaboratory comparison program in nongynecologic cytology. Arch Pathol Lab Med 2013;137:26-31.

8. Degirmenci B, Haktanir A, Albayrak R, et al. Sonographically guided fineneedle biopsy of thyroid nodules: the effects of nodule characteristics, sampling technique, and needle size on the adequacy of cytological material. Clin Radiol 2007;62:798-803.

9. Zhang L, Liu Y, Tan X, Liu X, Zhang H, Qian L. Comparison of DifferentGauge Needles for Fine-Needle Aspiration Biopsy of Thyroid Nodules. J Ultrasound Med 2018; 37:1713-1716.

10. Hanbidge $A E$, Arenson AM, Shaw PA, et al. Needle size and sample adequacy in ultrasound-guided biopsy of thyroid nodules. Can Assoc Radiol J 1995; 46:199-201.

11. Tangpricha V, Chen BJ, Swan NC, Sweeney AT, de las Morenas A, Safer JD. Twenty-one-gauge needles provide more cellular samples than twentyfive-gauge needles in fine-needle aspiration biopsy of the thyroid but may not provide increased diagnostic accuracy. Thyroid 2001; 11:973-6.

12. Jung SJ, Kim DW, Baek HJ. Comparison study of the adequacy and pain scale of ultrasound-guided fine needle aspiration of solid thyroid nodules with a 21- or 23- gauge needle for liquid-based cytology: a single-center study. Endocr Pathol 2018; 29:30-4.

13. Baloch ZW, Cooper DS, Gharib H, Alexander EK. Overview of diagnostic terminology and reporting. In: Ali SZ, Cibas ES, editors. The Bethesda System for Reporting Thyroid Cytopathology (2nd). New York: Springer Nature; 2018.p.1-6.

14. Gumus M, Cay N, Algin O, et al. Comparison of 21 and 27 gauge needles for determining sample adequacy in the aspiration biopsy of thyroid nodules. Diagn Interv Radiol 2012; 18:102-5.

15. Leboulleux S, Borget I, Labro S, et al. Frequency and intensity of pain related to thyroid nodule fine-needle aspiration cytology. Thyroid 2013; 23:1113-8.

16. Carpi A, Rossi G, Nicolini A, et al. Does large needle aspiration biopsy add pain to the thyroid nodule evaluation? PLoS One 2013; 8(3): e58016.

17. Lee YJ, Kim DW, Jung SJ. Comparison of sample adequacy, pain-scale ratings, and complications associated with ultrasound-guided fineneedle aspiration of thyroid nodules between two radiologists with different levels of experience. Endocrine 2013; 44:696-701.

18. Kwon J H, Kim D B, Han Y H, Cha Y K, Kim J S. Contributory Factors to Hemorrhage After Ultrasound-Guided Fine Needle Aspiration of Thyroid Nodules with an Emphasis on Patients Taking Antithrombotic or Anticoagulant Medications, Iran J Radiol. 2018; 15(2):e57231.

19. Redman R, Zalaznick H, Mazzaferri EL et al. The Impact of Assessing Specimen Adequacy and Number of Needle Passes for Fine-Needle Aspiration Biopsy of Thyroid Nodules. Thyroid 2006; 16:55-60.

20. Stacul F, Bertolotto $M$, Zappetti $R$, et al. The radiologist and the cytologist in diagnosing thyroid nodules: results of cooperation. Radiol Med 2007; 112:597-602.

21. Olson MT, Tatsas AD, Ali SZ. Cytotechnologist-Attended On-Site Adequacy Evaluation of Thyroid Fine-Needle Aspiration: Comparison With Cytopathologists and Correlation With the Final Interpretation, American Journal of Clinical Pathology 2012; 138(1):90-5. 